\title{
Randomized controlled clinical trial of digital and conventional workflows for the fabrication of zirconia-ceramic fixed partial dentures. Part I: Time efficiency of complete-arch digital scans versus conventional impressions
}

\author{
Sailer, Irena ; Mühlemann, Sven ; Fehmer, Vincent ; Hämmerle, Christoph H F ; Benic, Goran I
}

\begin{abstract}
STATEMENT OF PROBLEM Clinical trials are needed to evaluate digital and conventional technologies for providing fixed partial dentures. PURPOSE The purpose of the first part of this clinical study was to test whether complete-arch digital scans were similar to or better than complete-arch conventional impressions regarding time efficiency and participant and clinician perceptions. MATERIAL AND METHODS Ten participants in need of a posterior tooth-supported 3-unit fixed partial denture were included. Three intraoral digital scanners and subsequent workflows (Lava C.O.S.; 3M [Lava], iTero; Align Technology Inc [iTero], Cerec Bluecam; Dentsply Sirona [Cerec]) were compared with the conventional impression method using polyether (Permadyne; $3 \mathrm{M}$ ) and the conventional workflow. A computer-generated randomization list was used to determine the sequence of the tested impression procedures for each participant. The time needed for the impression procedures, including the occlusal registration, was assessed. In addition, the participant and clinician perceptions of the comfort and difficulty of the impression were rated by means of visual analog scales. Data were analyzed with the nonparametric paired Wilcoxon test together with an appropriate Bonferroni correction to detect differences among the impression systems $(\alpha=.05)$. RESULTS The total time for the complete-arch impressions, including the preparation (powdering) and the occlusal registration, was shorter for the conventional impression than for the digital scans (Lava $1091 \pm 523$ seconds, iTero $1313 \pm 418$ seconds, Cerec $1702 \pm 558$ seconds, conventional $658 \pm 181$ seconds). The difference was statistically significant for 2 of the 3 digital scanners (iTero $\mathrm{P}=.001$, Cerec $\mathrm{P}<.001$ ). The clinicians preferred the conventional impression to the digital scans. Of the scanning systems, the system without the need for powdering was preferred to the systems with powdering. No impression method was clearly preferred over others by the participants. CONCLUSIONS For complete-arch impressions, the conventional impression procedures were objectively less time consuming and subjectively preferred by both clinicians and participants over digital scan procedures.
\end{abstract}

DOI: https://doi.org/10.1016/j.prosdent.2018.04.021

Posted at the Zurich Open Repository and Archive, University of Zurich ZORA URL: https://doi.org/10.5167/uzh-153080

Journal Article

Accepted Version

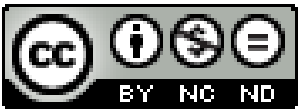

The following work is licensed under a Creative Commons: Attribution-NonCommercial-NoDerivatives 4.0 International (CC BY-NC-ND 4.0) License.

Originally published at: 
Sailer, Irena; Mühlemann, Sven; Fehmer, Vincent; Hämmerle, Christoph H F; Benic, Goran I (2019). Randomized controlled clinical trial of digital and conventional workflows for the fabrication of zirconia-ceramic fixed partial dentures. Part I: Time efficiency of complete-arch digital scans versus conventional impressions. Journal of Prosthetic Dentistry, 121(1):69-75.

DOI: https://doi.org/10.1016/j.prosdent.2018.04.021 
JPD-17-921

Randomized controlled clinical trial of digital and conventional workflows for the fabrication of zirconia-ceramic fixed partial dentures. Part I: Time efficiency of complete-arch digital scans versus conventional impressions

\begin{abstract}
Statement of problem. Clinical trials are needed to evaluate digital and conventional technology for providing fixed partial dentures (FPDs).

Purpose. The purpose of the first part of this clinical study was to test whether complete-arch digital scans were similar to or better than complete-arch conventional impressions regarding time efficiency and participant and clinician perceptions.
\end{abstract}

Material and methods. Ten participants in need of a posterior tooth-supported 3-unit FPD were included. Three intraoral digital scanners and subsequent workflows (Lava C.O.S.; 3M (Lava), iTero; Align Technology Inc (iTero), Cerec Bluecam; Dentsply Sirona (Cerec)) were compared with the conventional impression method using polyether (Permadyne; 3M) and the conventional workflow. A computer-generated randomization list was used to determine the sequence of the tested impression procedures for each participant. The time needed for the impression procedures, including the occlusal registration, was assessed. Additionally, the participant and clinician perceptions of the comfort and difficulty of the impression were rated by means of visual analog scales (VASs). Data were analyzed with the nonparametric paired Wilcoxon test together with an appropriate Bonferroni correction to detect differences among the impression systems $(\alpha=.05)$. 
Randomized controlled clinical trial of digital and conventional workflows for the fabrication of zirconiaceramic fixed partial dentures. Part I: Time efficiency of complete arch digital scans versus conventional impressions

Irena Sailer, Prof Dr med dent, ${ }^{,}$Sven Mühlemann, Dr med dent, ${ }^{,}$Vincent Fehmer, MDT ${ }^{\circ}$, Christoph H.F. Hämmerle, Prof Dr med dent, ${ }^{a}$ and Goran I. Benic, PD Dr med dent

Supported by the Clinic of Fixed and Removable Prosthodontics and Dental Material Science, Center of Dental Medicine, University of Zurich, Switzerland and by a research grant from Institut Straumann AG, Basel, Switzerland.

Professor, Division of Fixed Prosthodontics and Biomaterials, University Clinics for Dental Medicine, University of Geneva, Geneva, Switzerland.

${ }^{\triangleright}$ Senior Teaching and Research Assistant, Clinic of Fixed and Removable Prosthodontics and Dental Material Science, Center of Dental Medicine, University of Zurich, Zurich, Switzerland.

Master Dental Technician, Division of Fixed Prosthodontics and Biomaterials, University Clinics for Dental Medicine, University of Geneva, Geneva, Switzerland.

Professor, Clinic of Fixed and Removable Prosthodontics and Dental Material Science, Center of Dental Medicine, University of Zurich, Zurich, Switzerland.

Senior Teaching and Research Assistant, Clinic of Fixed and Removable Prosthodontics and Dental Material Science, Center of Dental Medicine, University of Zurich, Zurich, Switzerland. 
Corresponding author:

Prof. Irena Sailer

Division for Fixed Prosthodontics and Biomaterials

University Clinics for Dental Medicine

University of Geneva

19, rue Barthélemy- Menn

CH-1205 Geneva

SWITZERLAND

Email: irena.sailer@unige.ch

Acknowledgments:

The authors thank Mrs. Gisela Müller who supported the preparation and submission of this manuscript.

Basel, Switzerland. 
Results. The total time for the complete-arch impressions, including the preparation (powdering) and the occlusal registration was shorter for the conventional impression than for the digital scans (Lava $1091 \pm 523$ seconds, iTero $1313 \pm 418$ seconds, Cerec $1702 \pm 558$ seconds, conventional $658 \pm 181$ seconds). The difference was statistically significant for 2 of the 3 digital scanners (iTero $P=.001$, Cerec $P<.001$ ). The clinicians preferred the conventional impression to the digital scans. Of the scanning systems, the impression system without need for powdering was preferred to the systems with powdering. No impression method was clearly preferred over others by the participants.

Conclusions. For complete-arch impressions, the conventional impression procedures were objectively less time consuming, and subjectively preferred by both clinicians and participants over digital scan procedures.

\section{CLINICAL IMPLICATIONS}

In patients with a missing tooth and in need of a fixed partial denture, complete-arch digital scans were no better than conventional impressions, either after objective or subjective evaluations.

\section{INTRODUCTION}

Digital scans and subsequent computer-aided design and computer-aided manufacturing (CADCAM) workflows have become a common alternative to conventional manual workflows for the fabrication of dental prostheses. Many intraoral digital scanners have been marketed, and the systems purport to be fast, easy, efficient, and accurate. ${ }^{1}$ Conventional impressions with 
elastomeric materials and the associated manual fabrication of stone casts and the prostheses appear to be more and more outdated.

From a clinical perspective, the essential part of any restorative fabrication workflow is the accuracy of the resulting prosthesis. This accuracy depends on the accuracy of each step in the workflow, for example the impression, the definitive cast, and the design and fabrication of the restoration. ${ }^{2-4}$ Conventional elastomeric impressions exhibit excellent accuracy. ${ }^{5-7}$ Both partial as well as complete-arch impressions lead to reliable results. The accuracy of manually made prostheses depends on the definitive cast, the thickness of the die spacer, and the investment material used for the lost-wax technique. ${ }^{3}$ The accuracy of digital scans, in contrast, depends on the optical technology used, the need for application of scan powder, and the algorithm associated with the digital system.

The accuracy of digital scanners has been compared with conventional impressions, with similar accuracy reported for partial arch recordings. ${ }^{7}$ However, for complete-arch recording, digital scans led to less accurate results than conventional impressions exhibiting distortion of the scans in the molar region. ${ }^{5}$ Therefore, the current technology suggests that digital scans should be limited to single-unit and smaller multiple-unit prostheses. The efficiency of the procedure is also important for the selection of the restoration workflow. Impression systems and fabrication procedures need to be easy to use, fast, and cost effective. ${ }^{8}$

Conventional impression making is well established, the materials and the procedures are routinely applied, and the costs are limited. Digital scanning is associated with high acquisition costs and a time-consuming learning curve. The number of dental practices that have adopted digital scanning and the digital workflow is still small, despite the various options to integrate digital technologies into the workflow of prosthetic dentistry. ${ }^{8}$ To be adopted, digital procedures 
need to be at least as easy and fast and more versatile than the conventional procedures. Also, subjective appreciation of the different procedures seems to play an important role in changing clinical concepts. ${ }^{1,8}$ However, studies comparing the entire workflow starting from the scan to the insertion of the definitive prosthesis are scarce. Furthermore, the authors are unaware of studies that compared patient and operator centered outcomes with respect to the different workflows. Therefore, the purpose of this randomized controlled clinical trial (RCT) was to compare the overall performance of 3 different digital workflows and 1 conventional workflow for the fabrication of 3-unit posterior zirconia-ceramic fixed partial dentures, from the scan or impression to the delivery of the prosthesis.

The purpose of the first part of this study was to test whether the complete-arch digital scans were similar or better than the conventional complete-arch impression with respect to time efficienc, and the participant and clinician perceptions of the workflow. The null hypothesis was that no differences would be found between the digital scan and the conventional impressions.

\section{MATERIAL AND METHODS}

This study was designed as an RCT including within-subject comparison of 3 different scanning methods compared with a conventional impression control. The study was undertaken at the Clinic of Fixed and Removable Prosthodontics and Dental Material Science, Center of Dental Medicine, University of Zurich, Zurich, Switzerland. The protocol was approved by the local ethical committee (Kantonale Ethik-Kommission, Zurich, Switzerland) (Ref. KEK-ZH-Nr. 20110103/5). The present study followed an earlier RCT comparing the digital and conventional workflows for the fabrication of single crowns and testing of partial arch impression making. ${ }^{8-10}$ 
The general criteria for the inclusion of the participants and the procedures for the randomization were similar in the investigations and have been previously described in detail. ${ }^{8}$

Briefly, in the present study, 10 participants in need of a posterior tooth-supported 3-unit fixed partial denture (FPD) were included. All participants had to fulfill the following inclusion criteria: over 18 years of age, full-mouth plaque scores (FMPS) and full-mouth bleeding scores (FMBS) less than 25\%, no active periodontal disease, need for a tooth-supported FPD in a posterior region not supported by a third molar, abutment teeth without need for extensive pretreatment (for example absence of a periapical lesion), and adjacent and antagonist teeth healthy or adequately restored. A signed informed consent was obtained from all the participants.

Software (www.randomizer.org) was used to create a computer-generated list of 10 sequences of the 4 tested scanning or impression procedures. The impression sequences were concealed by means of sealed envelopes until the time of the clinical treatment phase of the abutment tooth impression.

The clinical treatments were performed by 3 calibrated clinicians (I.S., G.B., S.M.) experienced with the digital scanners and with ceramic CAD-CAM prostheses. The calibration consisted of the clinicians applying the respective manufacturer-recommended scan strategies identically with the tested digital scans systems several times before the investigation. The clinicians prepared the abutment teeth for the zirconia FPDs according to the guidelines published for CAD-CAM ceramic FPDs (Sturzenegger B, et al. Swiss Dent J 2000;110:131-9). ${ }^{11}$

The preparation comprised a shoulder margin with rounded internal angles, an axial wall total convergence of approximately 10 degrees, and the rounding of all line angles. After the abutment tooth preparation, interim FPDs were fabricated from an autopolymerizing composite resin (Protemp 3 Garant; 3M). The interim restorations were cemented with eugenol-free interim 
luting agent (Freegenol; GC Corp). Before scanning or impression making, 2 gingival displacement cords (Ultrapak; Ultradent Products, Inc) were inserted to ensure good visibility of the preparation margins. The sequence of these scanning or impression procedures was randomly determined to avoid bias. The randomization envelope indicating the sequence of scanning or impression was opened after the removal of the interim FPD and the cleaning of the abutment teeth. For each patient, 3 digital (test) scans and a conventional (control) impression were made of both jaws in the given order, with the occlusal registration as indicated per system. The 3 digital systems for the intraoral digital scan and intermaxillary registration tested were Lava C.O.S.; 3M (Lava), iTero; Align Technology Inc. (iTero), Cerec Bluecam; and Dentsply Sirona (Cerec). The same clinician carried out all the scanning and impression making on the assigned participants.

Before scanning with Lava and Cerec, a titanium dioxide powder was applied to the tooth surfaces (Vita Cerec Powder with Cerec Propellant; VITA). The complete-arch scans and occlusal registrations were made according to the guidelines for each system. The conventional impressions were made with light- and regular-body polyether materials (Permadyne; 3M) and metal stock impression trays. The occlusal registration was made with a silicone occlusal registration paste (Preciform; Merz Dental) in the maximum intercuspal position. The impression of the opposing arch was made with alginate (Cavex Alginate; Cavex).

The quality of the digital and the conventional impressions was controlled by evaluating the reproduction of the abutment teeth, the proximal surfaces at the adjacent teeth, and the occlusal surfaces. Impressions or scans not fulfilling the quality criteria were recorded and repeated. The impressions and the occlusal registrations were transferred to the dental laboratory either via the Internet for the digital workflow or conventionally. Detailed information on the 
transfer and processing of digital data and the fabrication of casts and FPDs is described in Part II of this investigation. ${ }^{11}$

The following outcome variables were assessed during the scanning and impression session: the time needed for the powdering, the impressions, and the occlusal registration, the time needed for the conventional impressions from the beginning of mixing to tray removal, and the number of impression remakes. After obtaining an impression fulfilling the quality criteria, participant and clinician perceptions of the impression procedure were rated by means of a visual analog scale (VAS). The VAS consisted of a 100-mm horizontal line with anchor terms at each end. The participants were asked to rate the comfort of the impression (anchor terms: very uncomfortable $=0$, comfortable $=100$ ). The clinicians were asked to rate the difficulty of the impression (anchor terms: simple $=0$, very difficult $=100$ ) and their comfort in using the impression (anchor terms: very uncomfortable $=0$, comfortable $=100$ ). The VAS answers were converted to a numerical format ranging from 0 to 100 for statistical analysis.

Descriptive statistics was computed for all the variables with statistical software (IBM SPSS Statistics v20; IBM Corp). The data distributions were represented with boxplots, and the data were reported by using means, standard deviations, ranges, and 95\% confidence intervals. The nonparametric paired Wilcoxon test was applied together with an appropriate Bonferroni correction to detect differences between the impression systems $(\alpha=.05)$.

\section{RESULTS}

Six women and 4 men with a mean age of 62 years (range: 49 to 77 years) were included. The abutment teeth for the FPDs were 6 molars and 6 premolars in the maxilla and 5 molars and 3 premolars in the mandible. The detailed objective time values for the tested scans and 
impressions are presented in Table 1. The total time for the complete-arch scans or impressions, including the powdering and the occlusal registration, was shorter for the conventional impression than for the digital scans. The difference was statistically significant for 2 of the 3 digital scanners (iTero $P=.001$, Cerec $P<.001$ ). For 1 of the digital scanners (Cerec), significantly more time was needed for the scan than for the other 2 systems (Lava $P=.006$, iTero $P=.005$ ). The scans had to be remade 3 times for one digital scanner (Lava), 7 times for another (iTero), and once for the conventional impression method.

The VAS values of the scan or impression comfort for participants and clinicians and for the difficulty of the impression for the clinicians is displayed in Table 2. Both the participants and the clinicians rated the digital scans less comfortable than the conventional impressions. A significant difference was found when the digital scanners involving powdering (Lava $P=.002$ patient rating; Cerec $P<.001$ clinician rating) were compared with the conventional impressions. Furthermore, impression procedures involving powdering were significantly more difficult for the clinicians than the conventional complete-arch impression (Lava $P=.002$, iTero $P=.010$, Cerec $P<.001)$.

The preferences for the impression methods for participants and clinicians are displayed in Table 3. In general, no impression method was clearly preferred over the others by the participants. One digital scanner (Lava) was preferred by 3 of the participants, 3 other participants preferred the conventional impression method. The remaining digital scanners (iTero, Cerec) were both preferred by 2 participants each. The preference of the clinicians was clearer (Table 4). The clinicians preferred the conventional to the digital scanners for the complete-arch impressions. For 6 of the 10 participants $(n=6)$ the clinicians preferred the conventional impression method to the other procedures. Finally, the impression system without 
any need for powdering was preferred to the 2 systems with a need for powdering (iTero $n=3$ versus Lava $\mathrm{n}=1$, Cerec $\mathrm{n}=0$ ).

\section{DISCUSSION}

In the present study, conventional complete-arch impressions were less time consuming than the tested digital scan procedures. Furthermore, in the subjective assessment of both participants and clinicians, the conventional complete-arch impressions were more comfortable than the digital scans. In addition, the systems demanding powdering of the scanned surfaces were less comfortable for the participants and were more difficult for the clinicians than the conventional impression. Therefore, the null hypothesis was rejected.

Recent clinical studies have analyzed the time efficiency of digital and conventional impression methods, ${ }^{8,12-14}$ with different reported outcomes depending on the methods evaluated and whether partial or complete-arch impressions were made. A comparison of the scan time and patient perception of complete-arch conventional impressions with alginate with complete-arch digital scans with 1 digital scanner (Lava C.O.S.) for the fabrication of orthodontic study casts ${ }^{12}$ reported that the conventional complete-arch impressions were significantly faster (7.6 minutes) than the digital scans (20.4 minutes) $)^{12}$; this is consistent with the results of the present study and another clinical investigation assessing the time efficiency and clinical outcomes of digital scans and conventional impressions. ${ }^{14}$ However, Yuzbasioglu et al ${ }^{14}$ reported the opposite, with shorter total times for the tested digital scanner than the conventional impression. The different findings demonstrate the importance of the type of digital scanner used and associated handling for the outcomes. The scanner (Cerec Omnicam; Dentsply Sirona) used in that study ${ }^{14}$ was not included in the present investigation, making comparison difficult. Another clinical investigation testing 
the cost effectiveness and time efficiency of the digital scans and the conventional impressions for the fabrication of single implant crowns ${ }^{13}$ also reported contrary results to those of the present study and the study of orthodontic casts. ${ }^{12}$ They reported ${ }^{13}$ significantly lower chairside times for digital scanning than for conventional impressions (27.3 versus 33.2 minutes). ${ }^{13}$ The validity of this study is problematic, since the digital scans (test) were partial scans and the conventional impressions (control) were complete-arch impressions. ${ }^{13}$

A second paper from the same patient cohort reported the patient-centered outcomes of the digital scans and conventional impressions and indicated that the participants preferred the digital scans. ${ }^{15}$ The reason for the differences may have been that the digital scans were only partial impressions, whereas the conventional impressions were complete-arch impressions. Patient preferences were only one scope of a study comparing partial digital scans and partial conventional impressions (occlusal registrations). As in the present study, in that investigation, no clear patient preferences for digital scans or conventional impressions were found. ${ }^{8}$ Furthermore, the clinicians reported more difficulties with the digital scans than the conventional impressions. One factor increasing the difficulty of the impression and reducing the comfort for both participants and clinicians was the need to powder the intraoral environment for some of the digital scanners. Grünheid et $\mathrm{al}^{12}$ reported that $73.3 \%$ of their participants preferred the conventional impressions with alginate, whereas only $26.7 \%$ preferred the intraoral scan with the tested impression system with powdering (Lava C.O.S.). In general, the studies reporting on better patient comfort with digital scans than with conventional impressions tested impression systems without powdering (such as Cerec Omnicam or iTero). ${ }^{14,15}$ The development of new digital scanners should focus on technologies which do not need powdering, time-consuming preparation steps such as the placement of gingival displacement cords, or moisture control. 
The present clinical study tested the efficiency and the acceptance of the entire digital and conventional workflows for the fabrication of tooth-supported multiunit FPDs, starting from the impression and including the insertion of the prostheses. The evaluation also included the analysis of the clinical fit of the restorations with the replica technique and the assessment of clinical quality.$^{16}$ The present report compares the outcomes of the digital scans with the conventional impression methods. Additional papers will report the outcomes of the subsequent steps within the workflows.

Limitations of this RCT include the small number of participants; nevertheless, the authors are unaware of another clinical study comparing all the benefits and shortcomings of the digital and the conventional workflows. Future investigations should include more participants to validate the present findings.

\section{CONCLUSIONS}

Within the limitations of this RCT, the following conclusions were drawn:

1. For complete-arch impressions, the conventional impression procedures are objectively less time consuming and subjectively preferred by both clinicians and participants to the digital scan procedures.

2. Digital scanners that require powdering are technically more difficult for the clinicians and less comfortable for the participants than other types of digital scans and conventional impressions. 


\section{REFERENCES}

1. Zimmermann M, Mehl A, Mormann WH, Reich S. Intraoral scanning systems - a current overview. Int J Comput Dent 2015;18:101-29.

2. Abduo J, Lyons K, Swain M. Fit of zirconia fixed partial denture: a systematic review. J Oral Rehabil 2010;37:866-76.

3. Buchi DL, Ebler S, Hammerle CH, Sailer I. Marginal and internal fit of curved anterior CAD/CAM-milled zirconia fixed dental prostheses: an in-vitro study. Quintessence Int 2014;45:837-46.

4. Schonberger J, Erdelt KJ, Baumer D, Beuer F. Marginal and internal fit of posterior three-unit fixed zirconia dental prostheses fabricated with two different CAD/CAM systems and materials. Clin Oral Investig 2017;21:2629-35.

5. Ender A, Attin T, Mehl A. In vivo precision of conventional and digital methods of obtaining complete-arch dental impressions. J Prosthet Dent 2016;115:313-20.

6. Ender A, Mehl A. In-vitro evaluation of the accuracy of conventional and digital methods of obtaining full-arch dental impressions. Quintessence Int 2015;46:9-17.

7. Ender A, Zimmermann M, Attin T, Mehl A. In vivo precision of conventional and digital methods for obtaining quadrant dental impressions. Clin Oral Investig 2016;20:1495-504.

8. Benic GI, Muhlemann S, Fehmer V, Hammerle CH, Sailer I. Randomized controlled withinsubject evaluation of digital and conventional workflows for the fabrication of lithium disilicate single crowns. Part I: digital versus conventional unilateral impressions. J Prosthet Dent 2016;116:777-82.

9. Sailer I, Benic GI, Fehmer V, Hammerle CHF, Muhlemann S. Randomized controlled withinsubject evaluation of digital and conventional workflows for the fabrication of lithium disilicate 
single crowns. Part II: CAD-CAM versus conventional laboratory procedures. J Prosthet Dent 2017;118:43-8.

10. Zeltner M, Sailer I, Muhlemann S, Ozcan M, Hammerle CH, Benic GI. Randomized controlled within-subject evaluation of digital and conventional workflows for the fabrication of lithium disilicate single crowns. Part III: marginal and internal fit. J Prosthet Dent 2017;117:35462.

11. Mühlemann S, Benic GI, Fehmer V, Hammerle C, Sailer I. Randomized controlled clinical trial of digital and conventional workflows for the fabrication of zirconia-ceramic posterior fixed partial dentures. Part II: Time efficiency of CAD-CAM versus conventional laboratory procedures. J Prosthet Dent 2018; In press.

12. Grunheid T, McCarthy SD, Larson BE. Clinical use of a direct chairside oral scanner: an assessment of accuracy, time, and patient acceptance. Am J Orthod Dentofacial Orthop 2014;146:673-82.

13. Joda $\mathrm{T}$, Bragger $\mathrm{U}$. Time-efficiency analysis comparing digital and conventional workflows for implant crowns: a prospective clinical crossover trial. Int J Oral Maxillofac Implants 2015;30:1047-53.

14. Yuzbasioglu E, Kurt H, Turunc R, Bilir H. Comparison of digital and conventional impression techniques: evaluation of patients' perception, treatment comfort, effectiveness and clinical outcomes. BMC Oral Health 2014;14:10.

15. Joda T, Bragger U. Patient-centered outcomes comparing digital and conventional implant impression procedures: a randomized crossover trial. Clin Oral Implants Res 2016;27:e185-e9. 
16. Benic GI, Sailer I, Zeltner M, Gütermann JN, Mühlemann S. Randomized controlled clinical trial of digital and conventional workflows for the fabrication of zirconia-ceramic fixed partial dentures. Part III: Marginal and internal fit. J Prosthet Dent 2018; submitted. 


\section{TABLES}

Table 1. Detailed data on times needed for different treatment steps for 3 digital scan systems and conventional impression procedure.

CI, confidence interval; SD, standard deviation. Results of nonparametric paired Wilcoxon test. "statistically significant

\begin{tabular}{|c|c|c|c|c|c|c|c|c|c|c|c|c|c|c|c|c|c|c|c|c|}
\hline Time & \multicolumn{5}{|c|}{ Lava } & \multicolumn{5}{|c|}{ iTero } & \multicolumn{5}{|c|}{ Cerec } & \multicolumn{5}{|c|}{ Conventional } \\
\hline & $\begin{array}{l}\text { Mean } \pm \\
\text { SD }\end{array}$ & Median & $95 \%$ CI & Range & $P$ & $\begin{array}{l}\text { Mean } \pm \\
\text { SD }\end{array}$ & Median & $95 \% \mathrm{CI}$ & Range & $P$ & $\begin{array}{l}\text { Mean } \pm \\
\text { SD }\end{array}$ & Median & $95 \% \mathrm{Cl}$ & Range & $P$ & $\begin{array}{l}\text { Mean } \pm \\
\text { SD }\end{array}$ & Median & $95 \%$ CI & Range & $P$ \\
\hline $\begin{array}{l}\text { Powdering } \\
\text { time (sec) }\end{array}$ & $80 \pm 35$ & 72 & $55-106$ & $29-144$ & & & & & & & $96 \pm 25$ & 89 & $39-92$ & $29-155$ & & & & & & \\
\hline $\begin{array}{l}\text { Impression/ } \\
\text { Scanning } \\
\text { time (sec) }\end{array}$ & $\begin{array}{l}1010 \pm \\
529\end{array}$ & 916 & $\begin{array}{l}632- \\
1389\end{array}$ & $\begin{array}{l}407- \\
1998\end{array}$ & $\begin{array}{l}\text { iTero } \\
.248 \\
\text { Cerec } \\
.633 \\
\text { Conv. } \\
1.000\end{array}$ & $\begin{array}{l}1313 \pm \\
418\end{array}$ & 1107 & $\begin{array}{l}1014- \\
1612\end{array}$ & $\begin{array}{l}785- \\
2091\end{array}$ & $\begin{array}{l}\text { Lava } \\
.248 \\
\text { Cerec } \\
.961 \\
\text { Conv. } \\
.023\end{array}$ & $\begin{array}{l}1604 \pm \\
542\end{array}$ & 1672 & $\begin{array}{l}1216- \\
1992\end{array}$ & $\begin{array}{l}721- \\
2247\end{array}$ & $\begin{array}{l}\text { Lava } \\
.633 \\
\text { iTero } \\
.961 \\
\text { Conv. } \\
.023\end{array}$ & $\begin{array}{l}658 \pm \\
181\end{array}$ & 641 & $\begin{array}{l}528-1 \\
782-\end{array}$ & $\begin{array}{l}395- \\
936-\end{array}$ & $\begin{array}{l}\text { Lava } \\
1.000 \\
\text { iTero } \\
.023 \\
\text { Cerec } \\
.023\end{array}$ \\
\hline $\begin{array}{l}\text { Total time } \\
\text { (sec) }\end{array}$ & $\begin{array}{l}1091 \pm \\
523\end{array}$ & 992 & $\begin{array}{l}717-5 \\
1465\end{array}$ & $\begin{array}{l}506- \\
2058\end{array}$ & $\begin{array}{l}\text { iTero } \\
.633 \\
\text { Cerec } \\
.633 \\
\text { Conv. } \\
.785\end{array}$ & $\begin{array}{l}1313 \pm \\
418\end{array}$ & 1107 & $\begin{array}{l}1014- \\
1612\end{array}$ & $\begin{array}{l}785- \\
2091\end{array}$ & $\begin{array}{l}\text { Lava } \\
.633 \\
\text { Cerec } \\
.387 \\
\text { Conv. } \\
.023\end{array}$ & $\begin{array}{l}1702 \pm \\
558\end{array}$ & 1776 & $\begin{array}{l}1303- \\
2101\end{array}$ & $\begin{array}{l}804- \\
2386\end{array}$ & $\begin{array}{l}\text { Lava } \\
.633 \\
\text { iTero } \\
.387 \\
\text { Conv. } \\
.012\end{array}$ & $\begin{array}{l}658 \pm \\
181\end{array}$ & 641 & $\begin{array}{l}528- \\
782\end{array}$ & $\begin{array}{l}395- \\
936-\end{array}$ & $\begin{array}{l}\text { Lava } \\
.785 \\
\text { iTero } \\
.023 \\
\text { Cerec } \\
.012\end{array}$ \\
\hline $\begin{array}{l}\text { Retakes//Ad } \\
\text { ditional } \\
\text { Scans (n/10) }\end{array}$ & & & 3 & & & & & 7 & & & & & 0 & & & & & 1 & & \\
\hline
\end{tabular}


Table 2. VAS patient and clinician evaluations of comfort and difficulty for 4 impression types. CI, confidence interval; SD, standard

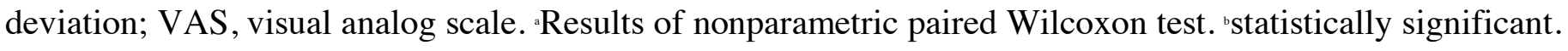

\begin{tabular}{|c|c|c|c|c|c|c|c|c|c|c|c|c|c|c|c|c|c|c|c|c|}
\hline & \multicolumn{5}{|c|}{ Lava } & \multicolumn{5}{|c|}{ iTero } & \multicolumn{5}{|c|}{ Cerec } & \multicolumn{5}{|c|}{ Conventional } \\
\hline & $\begin{array}{l}\text { Mean } \pm \\
\text { SD }\end{array}$ & Median & $\begin{array}{l}95 \% \\
\text { CI }\end{array}$ & Range & $P$ & $\begin{array}{l}\text { Mean } \pm \\
\text { SD }\end{array}$ & Median & $\begin{array}{l}95 \% \\
\text { CI }\end{array}$ & Range & $P$ & $\begin{array}{l}\text { Mean } \pm \\
\text { SD }\end{array}$ & Median & $\begin{array}{l}95 \% \\
\text { CI }\end{array}$ & Range & $P$ & $\begin{array}{l}\text { Mean } \pm \\
\text { SD }\end{array}$ & Median & $\begin{array}{l}95 \% \\
\text { CI }\end{array}$ & Range & $P$ \\
\hline $\begin{array}{l}\text { Patient's } \\
\text { preference: } \\
\text { Comfort }\end{array}$ & $35 \pm 27$ & 25 & $16-54$ & $4-96$ & $\begin{array}{c}\text { iTero } \\
.149 \\
\text { Cerec } \\
.434 \\
\text { Conv. } \\
.086\end{array}$ & $73 \pm 17$ & 74 & $60-85$ & $37-93$ & $\begin{array}{c}\text { Lava } \\
.149 \\
\text { Cerec } \\
1.000 \\
\text { Conv. } \\
1.000 \\
\end{array}$ & $57 \pm 25$ & 55 & $39-75$ & $12-95$ & $\begin{array}{c}\text { Lava } \\
.434 \\
\text { iTero } \\
1.000 \\
\text { Conv. } \\
.785 \\
\end{array}$ & $74 \pm 24$ & 82 & $57-91$ & $32-96$ & $\begin{array}{c}\text { Lava } \\
.086 \\
\text { iTero } \\
1.000 \\
\text { Cerec } \\
.785 \\
\end{array}$ \\
\hline $\begin{array}{l}\text { Clinician's } \\
\text { preference: } \\
\text { Difficulty }\end{array}$ & $48 \pm 26$ & 53 & $29-66$ & $29-66$ & $\begin{array}{c}\text { iTero } \\
1.000 \\
\text { Cerec } \\
.633 \\
\text { Conv. } \\
.055\end{array}$ & $43 \pm 26$ & 50 & $25-62$ & $11-87$ & $\begin{array}{c}\text { Lava } \\
1.000 \\
\text { Cerec } \\
.355 \\
\text { Conv. } \\
. \mathbf{0 2 3}\end{array}$ & $67 \pm 13$ & 69 & $58-77$ & $45-83$ & $\begin{array}{c}\text { Lava } \\
.633 \\
\text { iTero } \\
.355 \\
\text { Conv. } \\
.012\end{array}$ & $15 \pm 12$ & 11 & $7-24$ & $4-37$ & $\begin{array}{c}\text { Lava } \\
.055 \\
\text { iTero } \\
.023 \\
\text { Cerec } \\
.012\end{array}$ \\
\hline $\begin{array}{l}\text { Clinician's } \\
\text { preference: } \\
\text { Comfort }\end{array}$ & $55 \pm 23$ & 59 & $39-72$ & $0-81$ & $\begin{array}{c}\text { iTero } \\
1.000 \\
\text { Cerec } \\
1.000 \\
\text { Conv. } \\
.086\end{array}$ & $51 \pm 25$ & 55 & $33-69$ & $15-96$ & $\begin{array}{c}\text { Lava } \\
1.000 \\
\text { Cerec } \\
.633 \\
\text { Conv. } \\
.055\end{array}$ & $32 \pm 20$ & 38 & $18-46$ & $0-53$ & $\begin{array}{c}\text { Lava } \\
1.000 \\
\text { iTero } \\
.633 \\
\text { Conv. } \\
.0023\end{array}$ & $82 \pm 17$ & 88 & $69-94$ & $45-97$ & $\begin{array}{c}\text { Lava } \\
.086 \\
\text { TTero } \\
.055 \\
\text { Cerec } \\
.023\end{array}$ \\
\hline
\end{tabular}


Table 3. Subjective estimation of time needed for different impressions and preferences, as judged by participants. CI, confidence

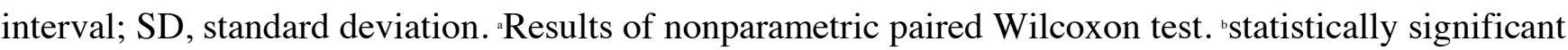

\begin{tabular}{|c|c|c|c|c|c|c|c|c|c|c|c|c|c|c|c|c|c|c|c|c|}
\hline \multirow{2}{*}{$\begin{array}{l}\begin{array}{l}\text { Patient's } \\
\text { preferences }\end{array} \\
\end{array}$} & \multicolumn{5}{|c|}{ Lava } & \multicolumn{5}{|c|}{ iTero } & \multicolumn{5}{|c|}{ Cerec } & \multicolumn{5}{|c|}{ Conventional } \\
\hline & $\begin{array}{l}\text { Mean } \\
\pm \text { SD }\end{array}$ & Median & $\begin{array}{l}\mathbf{9 5 \%} \% \\
\mathrm{CI}\end{array}$ & Range & $P$ & $\begin{array}{l}\text { Mean } \\
\pm \text { SD }\end{array}$ & Median & $\begin{array}{l}\mathbf{9 5 \%} \% \\
\text { CI }\end{array}$ & Range & $P$ & $\begin{array}{l}\text { Mean } \\
\pm \text { SD }\end{array}$ & Median & $\begin{array}{l}95 \% \\
\text { CI }\end{array}$ & Range & $P$ & $\begin{array}{l}\text { Mean } \\
\pm \text { SD }\end{array}$ & Median & $\begin{array}{l}95 \% \\
\text { CI }\end{array}$ & Range & $P$ \\
\hline $\begin{array}{l}\text { Estimated time } \\
\text { (sec) }\end{array}$ & $\begin{array}{c}1425 \pm \\
719\end{array}$ & 1350 & $\begin{array}{l}911- \\
1939\end{array}$ & $\begin{array}{l}510- \\
2700\end{array}$ & $\begin{array}{l}\text { iTero } \\
1.000 \\
\text { Cerec } \\
1.000 \\
\text { Conv. } \\
.143 \\
\end{array}$ & $\begin{array}{c}1530 \pm \\
767\end{array}$ & 1800 & $\begin{array}{l}981- \\
2079\end{array}$ & $\begin{array}{l}300- \\
2700\end{array}$ & $\begin{array}{c}\text { Lava } \\
1.000 \\
\text { Cerec } \\
1.000 \\
\text { Conv. } \\
.119 \\
\end{array}$ & $\begin{array}{c}1608 \pm \\
597\end{array}$ & 1500 & $\begin{array}{c}1181 \\
- \\
2035\end{array}$ & $\begin{array}{l}900- \\
2700\end{array}$ & $\begin{array}{l}\text { Lava } \\
1.000 \\
\text { iTero } \\
1.000 \\
\text { Conv. } \\
. .035 \\
\end{array}$ & $\begin{array}{c}840 \pm \\
428\end{array}$ & 630 & $\begin{array}{l}534- \\
1146\end{array}$ & $\begin{array}{l}300- \\
1800\end{array}$ & $\begin{array}{l}\text { Lava } \\
.143 \\
\text { iTero } \\
.119 \\
\text { Ceree } \\
. \mathbf{0 3 5} \\
\end{array}$ \\
\hline $\begin{array}{l}\text { Which } \\
\text { impression } \\
\text { would you } \\
\text { prefer? (n/10) }\end{array}$ & \multicolumn{5}{|c|}{3} & \multicolumn{5}{|c|}{2} & \multicolumn{5}{|c|}{2} & \multicolumn{5}{|c|}{3} \\
\hline $\begin{array}{l}\text { Which } \\
\text { impression } \\
\text { would you } \\
\text { NOT prefer? } \\
\text { (n/10) }\end{array}$ & \multicolumn{5}{|c|}{3} & \multicolumn{5}{|c|}{$\mathbf{0}$} & \multicolumn{5}{|c|}{3} & \multicolumn{5}{|c|}{4} \\
\hline
\end{tabular}


Table 4. Subjective estimation of time needed for different impressions and preferences, as judged by clinicians. CI, confidence

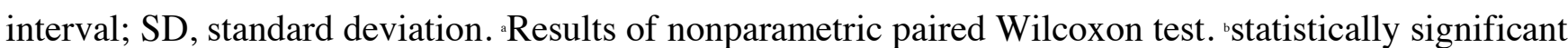

\begin{tabular}{|c|c|c|c|c|c|c|c|c|c|c|c|c|c|c|c|c|c|c|c|c|}
\hline \multirow{2}{*}{$\begin{array}{l}\text { Clinicians's } \\
\text { preferences }\end{array}$} & \multicolumn{5}{|c|}{ Lava } & \multicolumn{5}{|c|}{ iTero } & \multicolumn{5}{|c|}{ Cerec } & \multicolumn{5}{|c|}{ Conventional } \\
\hline & $\begin{array}{l}\text { Mean } \\
\pm \text { SD }\end{array}$ & Median & $\begin{array}{l}95 \% \\
\text { CI }\end{array}$ & Range & $P$ & $\begin{array}{l}\text { Mean } \pm \\
\text { SD }\end{array}$ & Median & $\begin{array}{l}95 \% \\
\text { CI }\end{array}$ & Range & $P$ & $\begin{array}{l}\text { Mean } \pm \\
\text { SD }\end{array}$ & Median & $\begin{array}{l}95 \% \\
\text { CI }\end{array}$ & Range & $P$ & $\begin{array}{l}\text { Mean } \pm \\
\text { SD }\end{array}$ & Median & $\begin{array}{l}95 \% \\
\text { CI }\end{array}$ & Range & $P$ \\
\hline $\begin{array}{l}\text { Estimated } \\
\text { time (sec) }\end{array}$ & $\begin{array}{c}1470 \pm \\
888\end{array}$ & 1200 & $\begin{array}{l}835- \\
2105\end{array}$ & $\begin{array}{l}600- \\
3000\end{array}$ & $\begin{array}{l}\text { iTero } \\
1.000 \\
\text { Cerec } \\
1.000 \\
\text { Conv. } \\
.296 \\
\end{array}$ & $\begin{array}{c}1422 \pm \\
530\end{array}$ & 1350 & $\begin{array}{l}1042- \\
1801\end{array}$ & $\begin{array}{l}720- \\
2400\end{array}$ & $\begin{array}{c}\text { Lava } \\
1.000 \\
\text { Cerec } \\
.469 \\
\text { Conv. } \\
.085 \\
\end{array}$ & $\begin{array}{c}1770 \pm \\
874\end{array}$ & 1800 & $\begin{array}{r}1145- \\
2395\end{array}$ & $\begin{array}{l}720- \\
3600\end{array}$ & $\begin{array}{c}\text { Lava } \\
1.000 \\
\text { iTero } \\
.469 \\
\text { Conv. } \\
.053 \\
\end{array}$ & $\begin{array}{c}930 \pm \\
500\end{array}$ & 630 & $\begin{array}{l}540- \\
1800\end{array}$ & $\begin{array}{l}540- \\
1800\end{array}$ & $\begin{array}{l}\text { Lava } \\
.296 \\
\text { iTero } \\
.085 \\
\text { Cerec } \\
.053 \\
\end{array}$ \\
\hline $\begin{array}{l}\text { Which } \\
\text { impression } \\
\text { would you } \\
\text { prefer? } \\
(\mathbf{n} / \mathbf{1 0})\end{array}$ & \multicolumn{5}{|c|}{1} & \multicolumn{5}{|c|}{3} & \multicolumn{5}{|c|}{$\mathbf{0}$} & \multicolumn{5}{|c|}{6} \\
\hline $\begin{array}{l}\text { Which } \\
\text { impression } \\
\text { would you } \\
\text { NOT prefer? } \\
\text { (n/10) } \\
\end{array}$ & \multicolumn{5}{|c|}{3} & \multicolumn{5}{|c|}{2} & \multicolumn{5}{|c|}{5} & \multicolumn{5}{|c|}{$\mathbf{0}$} \\
\hline
\end{tabular}

